KAVAKA 55: 77-83 (2020)

doi:10.36460/Kavaka/55/2020/77-83

\title{
Cultivation of a wild strain of Schizophyllum commune on agro-industrial wastes
}

\author{
Sanjit Debnath $^{1 *}$, Sanchita Bhattacharya ${ }^{1}$, Panna Das ${ }^{2}$ and Ajay Krishna Saha ${ }^{1}$ \\ ${ }^{1}$ Mycology and Plant Pathology Laboratory, Department of Botany, Tripura University, Suryamaninagar-799 022, Tripura, India. \\ ${ }^{2}$ Microbiology Laboratory, Department of Botany, Tripura University, Suryamaninagar-799 022, Tripura, India. \\ ${ }^{*}$ Corresponding author Email: sanjitdebnath2888@gmail.com
}

(Submitted on June 24, 2020; Accepted on November 17, 2020)

\begin{abstract}
The widely distributed macrofungal species Schizophyllum commune Fr. is one of the important mushrooms due to its diverse biological properties. The primary aim of this study was to collect and culture $S$. commune from the wild, taxonomically investigate, identify, cultivate, and evaluate its productivity and biological efficiency on natural substrate. The results revealed that sawdust with rice bran (1:1) was the most suitable substrate for cultivation of $S$. commune amongst the tested substrates with productivity ranging from 3.926-6.322 \% and biological efficiency from $7.55-12.157 \%$.S. commune is an easily cultivable wild edible mushroom and is a good source of nutraceuticals and medicines for maintaining and promoting human health.
\end{abstract}

KEYWORDS: Split gills, mushroom, agro-residues waste, cultivation techniques.

\section{INTRODUCTION}

Wild mushrooms are a crucial component of the forest ecosystem and are rich in secondary metabolites, proteins, carbohydrates, vitamins, minerals, fibres and low in fats. Because of their unique chemical composition, they are important from medicinal and nutraceutical point of view and exhibit antimicrobial, antifungal and antioxidant properties (Chowdhury et al., 2015). Nowadays the fresh and preserved mushrooms are consumed as food additives, especially for their specific aroma and texture (Kalač, 2012). Because of their taste, flavour and elevated dietary values, several medicinal mushrooms have been accepted as significant food products since ancient times (Khan and Tania, 2012). However, in the last few decades in comparison to vegetables, different biological properties of the wild mushroom species were evaluated so as to determine various components of dietary significance (Deepalakshmi and Mirunalini, 2014).

Out of the known mushrooms only a few of them are cultivated commercially on large scale throughout the world. Some of the known mushrooms are mycorrhizal and in the absence of suitable substrate they cannot be cultivated (Chakravarty, 2011). The worlds over mushrooms are cultivated on agricultural and industrial wastes, and in this way they play a major role in the recycling of organic residue (Elenwo and Okere, 2007). Number of organic substrate including agricultural crop residues, chicken and horse compost, cereal straw, industrial byproducts, paper industry residues, sawdust, etc. are in use for mushroom cultivation (Elenwo and Okere, 2007). Wild speciality mushrooms being a source of alternative natural food, are now being investigated and attempted for large scale cultivation (Hölker and Lenz, 2004; Pathmashini et al., 2008). In view of this the present attempt has been made for the domestication of wild sample of $S$. commune, which was to begin with, collected from the wild, cultured and taxonomically investigated employing both traditional and molecular taxonomic techniques.

\section{MATERIALS AND METHODS}

Collection site: The specimen was collected from the dead wood in the mixed forest bed of Mandwi (N 23⒚903' $\mathrm{E}$ $\left.091^{\circ} 29.192^{\prime}\right)$, West Tripura, Northeast India.
Culture preparation and preservation: The pure mycelia culture was raised from the basidiocarp on Potato Dextrose Agar (PDA) medium. The collected specimen was dried in hot air oven (Model: ROV/DG) at a constant temperature of $45-55^{\circ} \mathrm{C}$ for 24 hours and sealed in a polyethylene bag with 1 , 4-dichlorobenzene for further analysis (Debnath et al., 2017). The dry specimen was preserved in the Mycology and Plant Pathology Laboratory, Department of Botany, Tripura University, having the collection tag as MCCT (Mushroom Culture Collection Tube)-038.

Morphological identification: The mushroom sample was identified by consulting Pegler (1977) and Purkayastha and Chandra (1985). The different characteristics and measurements of basidiocarp like, habitat, shape, size, colour, and other features were recorded just after collection from the field. The specimen was hand-sectioned, and a small portion was squash-mounted in $5 \%$ potassium hydroxide $(\mathrm{KOH})$ solution. Slides were prepared in Lactophenol Cotton Blue Stain solution for documentation of characters under a bright field microscope (OLYMPUS Cx21i).

Molecular characterization: The total genomic DNA of the fungal specimen was extracted following the standard method of Sambrook et al. (1989). The PCR amplification was done using two universal primers (ITS1-5'-TCC GTA GGT GAA CCT GCG G -3' and ITS4-5'-TCC TCC GCT TAT TGA TAT GC -3'). The sufficient amount of amplicon product was purified by the $\mathrm{PEG}-\mathrm{NaCl}$ precipitation technique. DNA sequencing was carried out on an $A B I \circledast$ 3730XL automated DNA sequencer (Applied Biosystems, Inc., Foster City, CA) as per manufacturer's directions. DNA assembly was done by using the Lasergene package followed by NCBI BLAST. The identification of material was done following Boratyn et al. (2013).

DNA Sequence and phylogenetic analysis: The sequence was compared using NCBI BLAST and submitted in NCBI Database for obtaining accession numbers. The sequence was analysed by the Clustal W method using Mega 6.0 software. The neighbour-joining tree was constructed through Mega 6.0 software by applying 1000 bootstrap value with K2P (Kimura 2 parameter distances).

Media and culture: To obtain pure culture, a small piece of 
the mushroom tissue was placed on the sterilized Potato Dextrose Agar (PDA) media under aseptic conditions and kept for 7-10 days in an incubator at $25^{\circ} \mathrm{C}$ for sufficient growth. So as to purify the culture, repeated subculturing was done

Spawn Preparation: Fresh and healthy wheat grains free from debris, pest and moulds were used for mother spawn preparation. Mother spawn was prepared following the method described by Aneja (2003). Healthy grains were first washed with tap water for surface cleaning and then boiled for 15-20 min and excess water was drained off. The grains were dried in shade for 30 minutes and thoroughly mixed with calcium sulphate $(2 \%)$ and calcium carbonate $(0.5 \%)$ on dry weight $(\mathrm{w} / \mathrm{w})$ basis. After preparation of the grain-chemical mixture, $300 \mathrm{~g}$ grains were filled in $500 \mathrm{~mL}$ glass bottles and plugged with non-absorbent cotton. The bottles were allowed to cool to room temperature $\left(25-27^{\circ} \mathrm{C}\right)$ and inoculated with the mushroom mycelium (one $\mathrm{cm}$ cubes) of 7 days old mushroom culture. Loosely plugged glass bottles were incubated in an incubator for $15-20$ days at $25-27^{\circ} \mathrm{C}$ for the mycelia run.

Substrate preparation and Cultivation: Cultivation of the $S$. commune was tried on a variety of agro- residues, viz. paddy straw, mixed sawdust and rice bran. The substrate contained $2 \%$ of calcium sulphate $(\mathrm{w} / \mathrm{w})$ and $0.5 \%$ calcium carbonate (w/w), mixed thoroughly by hand and moisture was maintained at $80 \%$ by adding water.

Four types of substrates namely, paddy straw, sawdust, rice bran and mixture of sawdust: rice bran $(500 \mathrm{~g} /$ packet $)$ were inoculated with spawn by layer spawning technique in a polyethylene bag $(8.86 \times 11.81 \mathrm{inch})$ and compacted. The inoculated bags were sealed, wrapped with aluminium foil and kept in a dark incubation room $\left(23-27^{\circ} \mathrm{C}\right)$ and relative humidity was maintained between $70-80 \%$. The mycelium running rate on each substrate was observed daily and data was recorded. After complete spawn run, some holes (number of holes made per bag was 40 and size $1 \mathrm{~cm}$ in dia.) are made around the colonised bags and the bags were sprayed with cold water twice daily (Debnath et al., 2019).

Harvesting of mushroom: The mushroom yields on the different substrates were compared by modified methods of Morais et al. (2000) and Tisdale et al. (2006). Parameters taken were shortest mycelium running time in days, the time required for complete spawn run (RT) in days, the total number of primordia formation in all the three flushes, the time required for complete fruit body formation (PT) in days, number of mature basidiocarps, time required for primordia development to harvesting (HT) in days, duration of cropping $(\mathrm{T}=\mathrm{RT}+\mathrm{PT}+\mathrm{HT})$ in days.

Productivity and biological efficiency: The yield of mushroom is mainly dependent on the number of the fruit bodies formed, size of the fruit body, and yield per packet, which primarily accounts for productivity and biological efficiency.

Productivity (P) was calculated by the method of Andrade et al. (2008)
Productivity $(\mathrm{P}) \%=\mathrm{FWM} / \mathrm{FWC} \times 100$, where, $\mathrm{FWM}=$ fresh weight of mushroom and $\mathrm{FWC}=$ fresh weight of substrate.

Biological efficiency (BE) was calculated by method of Chang et al. (1981)

$\mathrm{BE} \%=\mathrm{FWM} / \mathrm{DWC} \times 100$, where, $\mathrm{FWM}=$ fresh weight of mushroom and DWC $=$ substrate dry weight.

Statistical analysis: All the calculations were done with the help of Past software version 2.17c (Hammer et al., 2001). All values were expressed as mean \pm standard error (SE) and experiments were done in triplicates. The experimental results were analyzed using one-way ANOVA (analysis of variance) following Tukey's honestly significant difference (HSD) test to test the significance among the different parameters of mushroom sample at $\mathrm{p}<0.05$.

\section{RESULTS}

\section{Taxonomic Description}

Schizophyllum commune Fr. Systema Mycologicum 1:330 (1821).

Figs.1 A-H

Distinguishing characters: Saprobic, solitary or gregarious. Basidiocarps 10-45 $\times 2-5 \mathrm{~mm}$, thin, flabelliform, laterally attached by a small base, surface dark grayish brown; margin lobed and deeply incised. Hymenophore smooth at initial stage becoming falsely lamellate, separable; lamellae edge incurved at first than splitting. Stipe absent. Basidiospore 3$5.5 \times 1-1.5 \mu \mathrm{m}$, cylindric, hyaline, smooth, thin-walled, minute. Basidia 14-25 $\times$ 5-6.5 $\mu \mathrm{m}$, clavate, tetra sterigmatic. Cystidia absent. Pileipellis, a cutis of elements 3-6 $\mu \mathrm{m}$ wide. Clamp connections present. Spore print white to light yellowish-white.

Global distribution: Cosmopolitan, distributed throughout the world.

Note: Edible (Purkayastha and Chandra, 1985), medicinal (Hobbs, 2005) and sometimes reported to cause allergic reaction(Liu et al., 2017).

Collection examined: Growing on dead wood in Mandwi, West Tripura, GPS (N 23⒚903' E 091²9.192') ; Collection number MCCT 038;

\section{Collectors: Upadhyay RC and Saha AK.}

Molecular characterization: The identification report was generated using NCBI Database and the confidence in identification is limited by both the availability and the extent of homology shown by the $\sim 700 \mathrm{bp}$ sequence of sample MCCT 038 with its closest neighbour in the database. The PCR amplification product for ITS 5.8S region was around $600-700 \mathrm{bp}$. Identity of the specimen was confirmed using ITS region sequences using NCBI BLAST. The sequence of the macrofungus was found to be the closest homolog of $S$. commune and there was $610 \mathrm{bp}$ sequenced. The ITS sequence for the macrofungus was deposited to NCBI under Accession number MH105058.

Phylogenetic analysis: A comparative ITS region-based phylogenetic analysis placed strain S. commune (MH105058) 

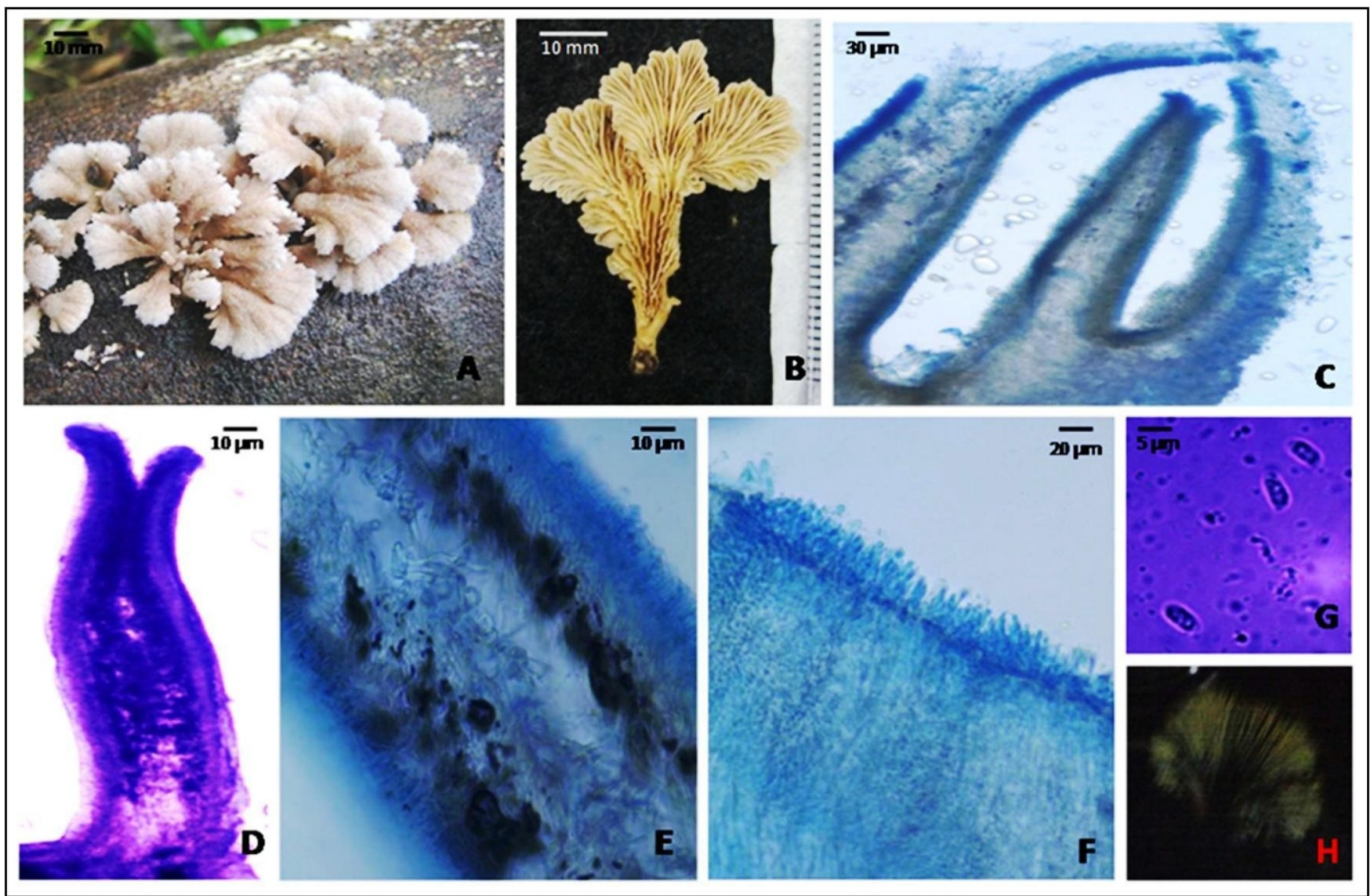

Fig. 1. (A-H) Macro and micro morphological features of $S$. commune- A: Dorsal side of basidiocarp; B.Ventral side of basidicarp; C: Cross section of pileus with splitting gills; D: Splitting gill; E: Basidia with hyphae; F: Basidia with basidiospores; G: Basidiospores; H: Spore print.

in a clade with the species of $S$. commune and revealed that in NCBI GenBank pair wise similarity of $99 \%$ was there (with

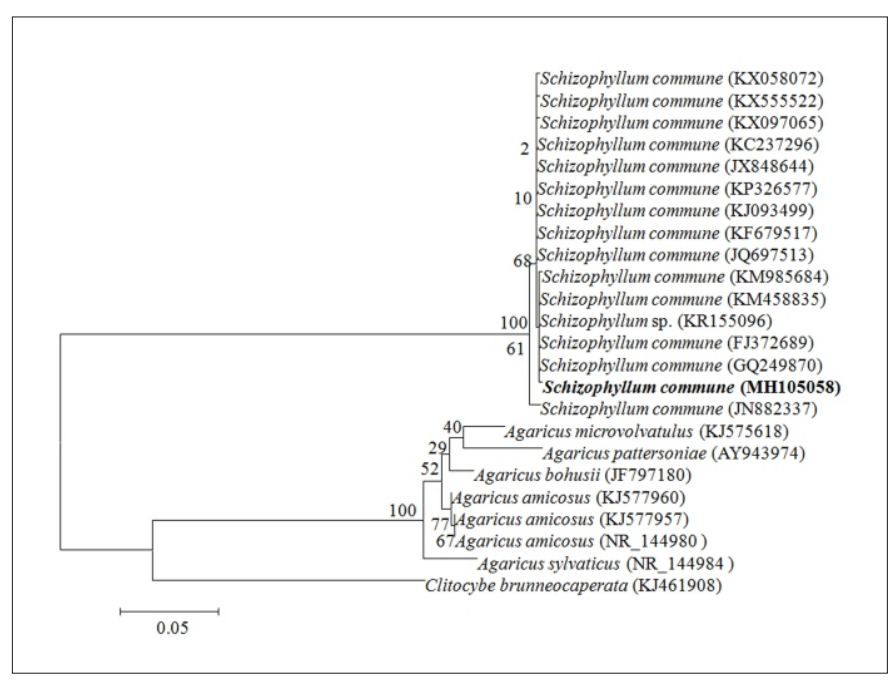

Fig. 2. Neighbour-joining phylogenetic tree of ITS sequences for $S$. commune and similar species from GenBank. Numbers above branches indicate values $>50 \%$ from 1000 bootstrap replicates of Neighbour-joining analyses.
KR155096 and KM458835). The bootstrap support found for the parent node is 100 . Based on the results from the phylogenetic tree and pairwise similarity results using GenBank and UNITE databases, it was inferred that the presently investigated strain belongs to $S$. commune (Fig 2).

Cultivation of $\boldsymbol{S}$. commune: The mushroom was cultivated using different substrates (Figs. 3A,B,C). Results indicated that variation in substrates has direct bearing on the number of primordia formed, number of the fruit bodies formed, size of fruit bodies and yield per packet (Fig 3). Mycelium running rate in cultivation bags varied remarkably on three types of substrates used for cultivation (sawdust, rice bran and mixture of sawdust: rice bran). No mycelia growth was observed in the paddy straw substrate.

The fastest mycelium run rate $(20.00 \pm 0.05$ days $)$ was observed in sawdust: rice bran $(1: 1$, w/w) mixture (Fig. 4A). The average number of primordia formed on different substrates differed significantly (Fig. 4B). The maximum number of primordia $(85.00 \pm 0.12,68.00 \pm 0.21$ and $40.00 \pm 0.22)$ and mature fruit bodies $(74.00 \pm 0.21,59.00 \pm 0.12$ and $38.00 \pm 0.50)$ per bag in all three flushes was found in sawdust: rice bran mixture $(1: 1, \mathrm{w} / \mathrm{w})$ and lowest in rice bran alone (Fig. 4B). Therefore, the time required for complete fruit body formation $(3.27 \pm 0.47,2.62 \pm 0.23$ and $1.23 \pm 0.45$ 

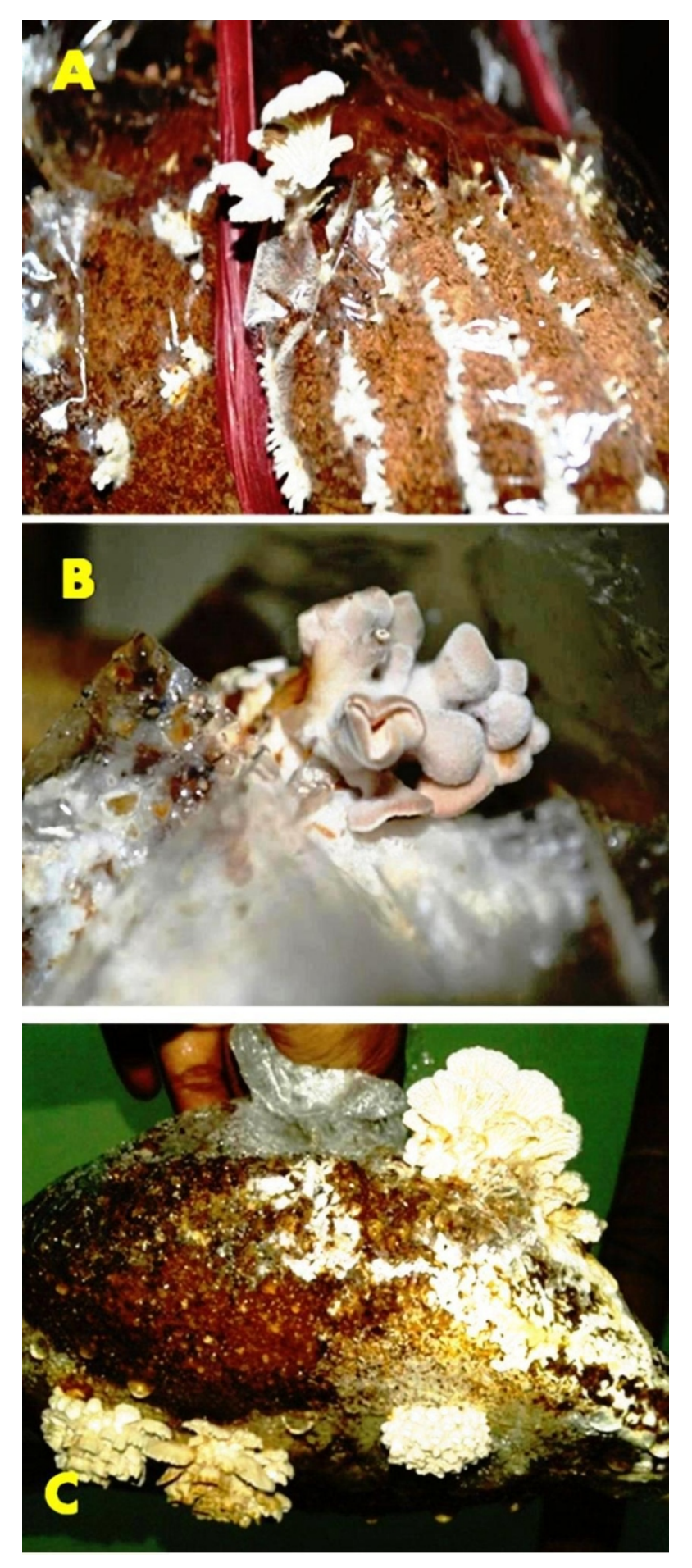

Fig.3. Cultivated $S$. commune on different types of substrates; A: only sawdust substrate, B: only rice bran substrate, $\mathrm{C}$ : sawdust and rice bran mixture $(1: 1)$

days) and time required from primordia formation to harvesting $(2.84 \pm 0.45,2.27 \pm 0.45$ and $1.54 \pm 0.61$ days $)$ in days was faster in three flushes of $S$. commune on sawdust: rice bran substrate in comparison to other two substrates (Fig. 4C). The sawdust:rice bran substrate produced the maximum number of fruiting bodies [74 (1st), 59 (2nd) and 40 (3rd)] in three flushes (Fig. 4B). Duration of cropping $(\mathrm{T}=$ $\mathrm{RT}+\mathrm{PT}+\mathrm{HT})$ was also significantly lesser in sawdust : rice bran mixture $(32.11 \pm 0.45,30.89 \pm 0.61$ and $20.77 \pm 0.05$ days $)$ in all the flushes (Fig 4D). The details about the size and thickness of the pileus, length and diameter of stipe are given in Table 1.

Biological yield, productivity and biological efficiency: Considerable variation was observed in the yield of mushrooms in the three types of substrates used (Fig 4). The maximum biological yield in different flushes (1st flush 31.61 gm, 2nd flush - 23.67 gm, and 3rd flush - $19.63 \mathrm{gm}$ ) was obtained in sawdust : rice bran $(1: 1, \mathrm{w} / \mathrm{w})$ substrate whereas Rice bran substrate gave the minimum yield of $8.55 \mathrm{gm}, 2.95$ gm and $0.00 \mathrm{gm}$ in three flushes, respectively (Fig 4E).

Mushroom yield in different flushes varied in different substrates. All the flushes of $S$. commune on sawdust: rice bran substrate showed reasonably higher per cent productivity (3.926-6.322\%) and biological efficiency (7.55$12.157 \%$ ) in comparison to sawdust and rice bran individually (Fig. 4F). No mycelia growth was observed in the paddy straw substrate. One way ANOVA was applied for determining the significance of the effect of various substrates on growth and yield parameters of $S$. commune, the results of which are presented in Table 2.

\section{DISCUSSION}

Wild $S$. commune is an edible mushroom, which contains a good amount of nutrients with antibacterial and antioxidant properties (Debnath et al., 2017). Amongst the physical parameters of this mushroom investigated, $25^{\circ} \mathrm{C}$ as optimum temperature, 21 days as incubation time and 6.0 as the medium $\mathrm{pH}$ were found to favour good mycelia growth under submerged cultivation (Debnath etal.,2017).

Dasanayaka and Wijeyaratne (2017) documented best yield when sawdust: rice bran were used in the ratio of $2: 1$. As compared presently maximum yield was obtained when sawdust: rice bran was used in the ratio of 1:1. Herawati et al. (2016) while working with S. commune documented very quick growth of mushroom in which first flush appeared within 17 days of inoculation and the total production was 1,198.71 g. Ediriweera et al. (2015) documented highest rate for mycelia growth and yield in case of $S$. commune when banana $(10.345 \pm 0.02 \mathrm{~cm} /$ week $)$ and coconut leaf $(9.589 \pm$ $0.66 \mathrm{~g}$ ) were used as substrates, however no mycelia growth was reported on paddy straw substrate. During the present investigation also, no growth was there on paddy straw substrate. Contrary to the present findings, Figlas et al. (2014) documented higher biological efficiency $(48.3 \%)$ but lower productivity $(1.6 \%)$ of $S$. commune when a mixture of sunflower seed hull and wheat bran was used as substrates. Moonmoon et al. (2011) reported that the yield of mushroom increased with the level of each supplementation up to a certain level and then decreased. Sawdust supplemented with $25 \%$ wheat bran is reported to produce the highest number of fruiting bodies (34.8/500 g packet), highest biological yield (153.3/500 g packet) and biological efficiency (76.6\%) in case of Lentinula edodes (Moonmoon et al. 2011). Preecha et 
Table 1: Basidiocarp size of cultivated S. commune on different types of substrates.

\begin{tabular}{|l|c|c|c|c|c|}
\hline \multirow{2}{*}{ Characters } & \multirow{2}{*}{ Basidiocarp } & \multicolumn{4}{|c|}{ Substrates } \\
\cline { 3 - 7 } & & \multicolumn{4}{|c|}{ Length and breadth of fruit body (cm) } \\
\cline { 3 - 7 } & Sawdust & Rice bran & $\begin{array}{c}\text { Sawdust +Rice } \\
\text { bran (1:1) }\end{array}$ & $\begin{array}{c}\text { Paddy } \\
\text { straw }\end{array}$ \\
\hline \multirow{3}{*}{ S. commune } & Sileus (cm) & $1.2-1.86 \times 0.56-1.08$ & $1.02-1.22 \times 0.2-0.60$ & $1.3-2.07 \times 1.12-1.90$ & No \\
\cline { 2 - 6 } & Stipe (cm) & Not formed & Not formed & Not formed \\
observed
\end{tabular}

al. (2015) evaluated mixture of different substrates, i.e. fresh sawdust and waste content (reusing cultivated spawn) in varied proportions for the cultivation of $S$. commune.

\section{CONCLUSION}

Based on overall findings, it can be concluded that, using variety of biodegradable agro-wastes could be a profitable
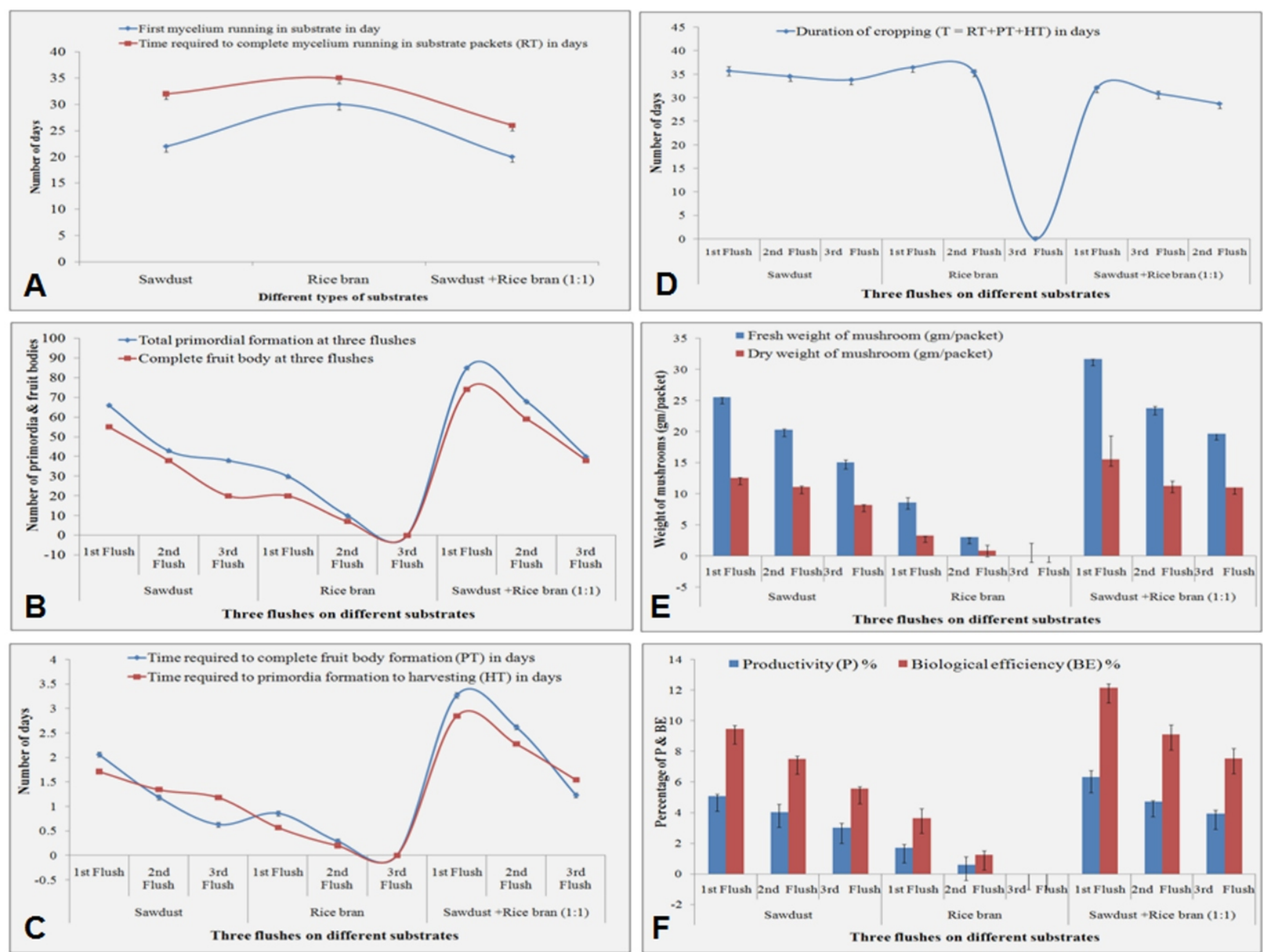

Fig. 4. Different yield parameters of cultivated $S$. commune on three different types of substrates. A: Mycelium running rate in three types of substrates, B: Total number of primordia and fruit body formation in three types of substrates, C: Time required to complete fruit body and primordia formation to harvesting in days on three types of substrates, D: Total numbers of days for cropping in three types of substrates, E: Fresh and dry weight (gm/packet) of cultivated $S$. commune in three types of substrates, F: Productivity (P) and Biological efficiency (BE) percentage in three different types of substrates. 
Table 2: One way ANOVA for effect of various substrates on growth and yield parameters of $S$. commune.

\begin{tabular}{|c|c|c|c|c|c|c|c|c|c|c|c|c|c|c|c|c|}
\hline \multirow{2}{*}{$\begin{array}{c}\text { Growth } \\
\text { characteristics }\end{array}$} & \multirow[b]{2}{*}{$\begin{array}{l}\text { Source of } \\
\text { Variation }\end{array}$} & \multicolumn{5}{|c|}{ First flushes of SD, RB and SDRB } & \multicolumn{5}{|c|}{ Second flushes of SD, RB and SDRB } & \multicolumn{5}{|c|}{ Third flushes of SD, RB and SDRB } \\
\hline & & $S S$ & $d f$ & $M S$ & $F$ & P-value & SS & $d f$ & $M S$ & $F$ & P-value & SS & $d f$ & $M S$ & $F$ & P-value \\
\hline \multirow{3}{*}{$\begin{array}{c}\text { Total } \\
\text { primordia } \\
\text { formation } \\
\text { in three } \\
\text { flushes }\end{array}$} & $\begin{array}{c}\text { Between } \\
\text { Groups }\end{array}$ & 4682 & 2 & 2341 & 152.6739 & $7.16 \mathrm{E}-06$ & 5078 & 2 & 2539 & 317.375 & $8.21 \mathrm{E}-07$ & 3048 & 2 & 1524 & 2286 & $2.25 \mathrm{E}-09$ \\
\hline & $\begin{array}{c}\text { Within } \\
\text { Groups }\end{array}$ & 92 & 6 & 15.33333 & & & 48 & 6 & 8 & & & 4 & 6 & 0.666667 & & \\
\hline & Total & 4774 & 8 & & & & 5126 & 8 & & & & 3052 & 8 & & & \\
\hline \multirow{3}{*}{$\begin{array}{c}\text { Complete } \\
\text { fruit body } \\
\text { formation } \\
\text { in three } \\
\text { flushes }\end{array}$} & $\begin{array}{c}\text { Between } \\
\text { Groups }\end{array}$ & 4502 & 2 & 2251 & 1125.5 & $1.88 \mathrm{E}-08$ & 4106 & 2 & 2053 & 1026.5 & $2.47 \mathrm{E}-08$ & 2168 & 2 & 1084 & 325.2 & $7.64 \mathrm{E}-07$ \\
\hline & $\begin{array}{c}\text { Within } \\
\text { Groups }\end{array}$ & 12 & 6 & 2 & & & 12 & 6 & 2 & & & 20 & 6 & 3.333333 & & \\
\hline & Total & 4514 & 8 & & & & 4118 & 8 & & & & 2188 & 8 & & & \\
\hline \multirow{3}{*}{$\begin{array}{c}\text { Fresh } \\
\text { weight of } \\
\text { mushroom } \\
\text { (gm/packet) }\end{array}$} & $\begin{array}{c}\text { Between } \\
\text { Groups }\end{array}$ & 856.5708 & 2 & 428.2854 & 171.1172 & $5.11 \mathrm{E}-06$ & 738.8753 & 2 & 369.4376 & 634.6393 & $1.04 \mathrm{E}-07$ & 631.9356 & 2 & 315.9678 & 1243.913 & $1.39 \mathrm{E}-08$ \\
\hline & $\begin{array}{c}\text { Within } \\
\text { Groups }\end{array}$ & 15.01727 & 6 & 2.502878 & & & 3.492733 & 6 & 0.582122 & & & 1.524067 & 6 & 0.254011 & & \\
\hline & Total & 871.588 & 8 & & & & 742.368 & 8 & & & & 633.4596 & 8 & & & \\
\hline \multirow{3}{*}{$\begin{array}{c}\text { Dry weight } \\
\text { of } \\
\text { mushroom } \\
\text { (gm/packet) }\end{array}$} & $\begin{array}{c}\text { Between } \\
\text { Groups }\end{array}$ & 245.3242 & 2 & 122.6621 & 486.4111 & $2.3 \mathrm{E}-07$ & 212.1422 & 2 & 106.0711 & 1431.244 & $9.15 \mathrm{E}-09$ & 361.4432 & 2 & 180.7216 & 440.6411 & $3.09 \mathrm{E}-07$ \\
\hline & $\begin{array}{c}\text { Within } \\
\text { Groups }\end{array}$ & 1.513067 & 6 & 0.252178 & & & 0.444667 & 6 & 0.074111 & & & 2.4608 & 6 & 0.410133 & & \\
\hline & Total & 246.8372 & 8 & & & & 212.5868 & 8 & & & & 363.904 & 8 & & & \\
\hline \multirow{3}{*}{$\begin{array}{l}\text { Productivity } \\
\text { (P) } \%\end{array}$} & $\begin{array}{c}\text { Between } \\
\text { Groups }\end{array}$ & 34.12776 & 2 & 17.06388 & 192.9151 & $3.59 \mathrm{E}-06$ & 29.49292 & 2 & 14.74646 & 974.0639 & $2.89 \mathrm{E}-08$ & 25.2128 & 2 & 12.6064 & 144.5136 & $8.41 \mathrm{E}-06$ \\
\hline & $\begin{array}{c}\text { Within } \\
\text { Groups }\end{array}$ & 0.530717 & 6 & 0.088453 & & & 0.090835 & 6 & 0.015139 & & & 0.5234 & 6 & 0.087233 & & \\
\hline & Total & 34.65848 & 8 & & & & 29.58376 & 8 & & & & 25.7362 & 8 & & & \\
\hline \multirow{3}{*}{$\begin{array}{c}\text { Biological } \\
\text { efficiency } \\
\text { (BE) \% }\end{array}$} & $\begin{array}{c}\text { Between } \\
\text { Groups }\end{array}$ & 113.2601 & 2 & 56.63004 & 268.4164 & $1.35 \mathrm{E}-06$ & 102.5307 & 2 & 51.26535 & 148.2499 & $7.8 \mathrm{E}-06$ & 93.9806 & 2 & 46.9903 & 6501.648 & $9.81 \mathrm{E}-11$ \\
\hline & $\begin{array}{l}\text { Within } \\
\text { Groups }\end{array}$ & 1.26587 & 6 & 0.210978 & & & 2.074822 & 6 & 0.345804 & & & 0.043365 & 6 & 0.007227 & & \\
\hline & Total & 114.526 & 8 & & & & 104.6055 & 8 & & & & 94.02397 & 8 & & & \\
\hline$p-$ & $<0.05 \mathrm{i}$ & ates th & & sign & 19 & & wth $\mathrm{cl}$ & & tics of & & & $\mathrm{PD}$. & & SDRE & duct & bran, \\
\hline
\end{tabular}

eco-friendly option for cultivation of speciality mushrooms like $S$. commune.

\section{ACKNOWLEDGEMENTS}

The authors are grateful to the Head, Department of Botany, Tripura University for providing all sorts of facilities and to the Forest Department of Tripura, Government of Tripura, India, for giving permission for field work in forest areas. All the authors are also thankful to the National Centre for Microbial Resource, Sai Trinity Building, Central Tower, Garware Circle, Sutarwadi, Pashan, Pune 411021, Maharashtra, India for molecular identification of mushroom. The first author is thankful to the Department of Biotechnology (DBT), Ministry of Science and Technology, Government of India for the financial assistance received through a project (Sanctioned order no. BT/463/NE/TBP/ 2013).

\section{REFERENCES}

Andrade, M.C.N., Zied, D.C., Minhoni, M.T.A. and Filho, J.K. 2008. Yield of four Agaricus bisporus strains in three compost formulations and chemical composition analyses of the mushrooms. Braz. J. Microbiol.39 (3): 593-598. https ://doi.org/10.1590/ s1517-838220080003000034.

Aneja, K.R. 2003. Mushroom production technology. In: Experiments in microbiology, Plant Pathology and Biotechnology. New Age International Pvt. Ltd. New-Delhi. pp 496-519.

Boratyn, G.M., Camacho, C., Cooper, P.S., Coulouris, G., Fong, A., Ma, N., Madden, T.L., Matten, W.T., Mcginnis, S.D., Merezhuk, Y., Raytselis, Y., Sayers, E.W., Tao, T., Ye, J. and Zaretskaya, I. 2013. BLAST: A more efficient report with usability improvements. Nucleic. Acids. Res. 41: 29-33.
Chakravarty, B. 2011. Trends in Mushroom cultivation and breeding. Aust. J. Agric. Eng. 2: 102-109.

Chang, S.T., Lau, O.W. and Cho, K.Y. 1981. The cultivation and nutritive value of Pleurotus sojor-caju. Eur. J. Appl. Microbiol. Biotechnol. 12: 58. https ://doi.org/ 10.1007/BF005 08120.

Chowdhury, M., Kubra, K. and Ahmed, S. 2015. Screening of antimicrobial, antioxidant properties and bioactive compounds of some edible mushrooms cultivated in Bangladesh. Ann. Clin. Microbiol. Antimicrob. 14: 8. https://doi.org/10.1186/s12941-015-0067-3.

Dasanayaka P.N. and Wijeyaratne, S.C. 2017. Cultivation of Schizophyllum commune mushroom on different wood substrates. JTFE. 7(1): 65-73.

Debnath, S., Saha, A.K. and Das, P. 2017 Biological Activities of Schizophyllum commune Fr.: A Wild Edible Mushroom of Tripura, North East India. $J$. Mycopathol. Res. 54 (4): 469-475.

Debnath, S., Saha, R., Das, P. and Saha, A.K. 2019. Cultivation and medicinal properties of wild edible Pleurotus ostreatus of Tripura, Northeast India. Vegetos. 32: 238-246. Https://doi.org/10.1007/s425 35-019-00035-2

Deepalakshmi, K. and Mirunalini, S. 2014. Pleurotus ostreatus: an oyster mushroom with nutritional and medicinal properties. J. Biochem. Technol. 5: 718726.

Ediriweera, S.S., Wijesundera, R.L.C., Nanayakkara, C.M. and Weerasena, O.V.D.S.J. 2015. Comparative study of growth and yield of edible mushrooms, Schizophyllum commune Fr., Auricularia polytricha (Mont.) Sacc. and Lentinus squarrosulus Mont. on 
lignocellulosic substrates. Mycosphere 6 (6): 760 765 .

Elenwo, E.N. and Okere, S.E. 2007. Waste recycling using edible mushroom cultivation. JASEM 11 (3): 153 156.

Figlas, D., González Matute, R., Delmastro, S. and Curvetto, N. 2014. Sunflower seed hulls for log system cultivation of Schizophyllum commune. Micol. Apl. Int. 26(2): 19-25.

Herawati, E., Arung, E. T. and Amirta, R. 2016. Domestication and nutrient analysis of Schizopyllum commune, alternative natural food sources in East Kalimantan. Agric. Agric. Sci. Procedia. 9: 291-296. Doi:10.1016/ j.aaspro. 2016.02.125

Hammer, O., Harper, D. and Ryan, P. 2001. PAST: Paleontological Statistics Software Package for Education and Data Analysis. Palaeontol. Electron. 4: $1-9$.

Hobbs, C. 2005. The chemistry, nutritional value, immunopharmacology, and safety of the traditional food of medicinal split-gill fugus Schizophyllum commune Fr.:Fr. (Schizophyllaceae). A Literature Review. Int. J. Med. Mushrooms 7/1(2): 127-140.

Hölker, U. and Lenz, J. 2004. Trickle-film processing: An alternative for producing fungal enzymes. BIOforum. Eur. 6: 55-57.

Kalač, P. 2012. A review of chemical composition and nutritional value of wild-growing and cultivated mushrooms. J. Sci. Food Agric. 93 (2): 209-218.

Khan, M.A. and Tania, M. 2012. Nutritional and Medicinal Importance of Pleurotus Mushrooms: An Overview. Food Rev. Int. 28: 313-329.

Liu, X., Zou, H., Chen, Q.J. and Lu, C.M. 2017. Allergic fungal sinusitis caused by Schizophyllum commune. World J. Otorhinolaryngol. Head. Neck. Surg. 3 (1): 59-63.
Moonmoon, M., Shelly, N.J., Khan, M.A., et al. 2011. Effects of different levels of wheat bran, rice bran and maize powder supplementation with saw dust on the production of shiitake mushroom (Lentinus edodes (Berk.) Singer). Saudi J. Biol. Sci. 18 (4): 323-328. doi:10.1016/j.sjbs.2010.12.008

Morais, M.H., Ramos, A.C., Matos, N., Santos and Oliveira, E.J. 2000. Note: production of shiitake mushroom (Lentinus edodes) on ligninocellulosic residues. Food. Sci. Technol. Int. 6: 123-128. https ://doi. org/10.1177/108201320000600206

Pathmashini, L., Arulnandhy, V. and Wilson Wijeratnam, R.S. 2008. Cultivation of oyster mushroom (Pleurotus ostreatus) on sawdust. J. Sci. (Biological Sciences) 37 (2): 177-182.

Pegler, D. N. 1977. A Preliminary agaric flora of East Africa.Kew Bull. Addit. Ser. 6: pp. 1-615.

Preecha, C., Wisutthiphaet, W., Seephueak, P. and Thongliumnak, S. 2015. Development of spawn culture material from reused spawn for cultivation split gill mushroom (Schizophyllum commune). Journal of Agricultural Technology 11(8): 2177 2181.

Purkayastha, R.P. and Chandra, A. 1985. Manual of Indian Edible Mushroom. Today and Tomorrow Printer and Publisher, New Delhi: 266.

Sambrook, J., Fritsch, E.F. and Maniatis, T.A. 1989. Molecular cloning: A laboratory manual. $2^{\text {nd }}$ ed. Cold Spring Harbor, NY: Cold Spring Harbor Laboratory Press; pp. 745.

Tisdale, T.E., Miyasaka, S.C. and Hemmes, D.E. 2006. Cultivation of the oyster mushroom (Pleurotus ostreatus) on wood substrates in Hawaii. World. J. Microbiol. Biotechnol. 22: 201-206. https ://doi. org/10.1007/s1127 4-005-9020-5. 